\title{
Note from the Editor
}

In April 1918, as Randolph Bourne was articulating his view that "TransNational America" had a special place in the modern world-the story recounted by Christopher Nichols in this issue-Bourne's friend Van Wyck Brooks published in the Dial his remarkable essay, "On Creating a Usable Past." Though more concerned with literature than history, Brooks nonetheless observed that "our historians... have held over the dark backward of time the divining-rods of their imagination and conjured out of it what they wanted and what their contemporaries wanted." Under the influence of the New History of the Progressive Era, intellectual iconoclasts such as Brooks and Bourne insisted not on transcending the impulse to impose present concerns and attitudes upon the past but on making those concerns broader and more humane. Of course, every sophisticated historian acknowledges that we cannot be arbitrary in our readings of the past and the use we make of it. History may not be a science, but it is a discipline, bound by conventions and standards concerning evidence, context, imagination, empathy, and analysis. Historians feel most secure in their assertions about the past when they have engaged in a dialogue with it rather than a monologue about it.

In his essay, Nichols demonstrates the multiple layers on which the concept of a usable past can operate. First, there is the past that seemed usable to Bourne. Anxious over the threat that war and great power politics posed to the open-ended and open-minded cultural tendencies he cherished, Bourne drew upon the isolationist tradition in American thought to argue that the United States could be engaged in the world without being entangled in it and without the country's most admirable ideals (as he understood these) being corrupted by nationalism, authority, and organization. Surely Bourne distorted the past in drawing upon it. How does one separate isolationism from Manifest Destiny and Anglo-American chauvinism, both of which were anathema to his vision of a transnationalist America? Nevertheless, Nichols self-consciously uses this story to support his own usable past by explicitly tracing Bourne's non-interventionist arguments forward to present-day exponents of the view that endless interventionism poses an intolerable danger to the country's principles.

The three contributors to this issue's forum on Michael Kazin's wellreceived recent biography of William Jennings Bryan, $A$ Godly Hero, engage in a high-level debate over the degree to which present-day concerns can responsibly animate interest in the past. Over his career, Kazin has won much praise for the subtle way he has drawn upon contemporary political commitments to produce research and writing with undoubted historical 
integrity. He concedes the "political subtext" of his Bryan biography to be the frustrating, damaging alienation of American liberalism from the evangelical and prophetic reform traditions that Bryan represented. Yet in the end, the three discussants in the forum-which originated as a seminar at Notre Dame University's Cushwa Center-concur with greater or lesser regret that fidelity to the evidence forces one to conclude that Bryan was too flawed a character and his circumstances too different from ours for his example to transcend the "instruct[ive]" and become "inspiring."

The remaining essays concern, respectively, a past that should probably be used more and a past that mercifully is not used much anymore. Joseph Horowitz's profile of music critic Henry Krehbiel continues the themes of Horowitz's excellent 2004 essay in this journal explicating Gilded Age musical culture. Figures such as Krehbiel, indicative of the intellectual ferment of turn-of-the-century New York, disappear from view because the German American milieu has irretrievably dissipated and because historians persistently misapprehend music's role in Gilded Age thought and expresssion. Bluford Adams, meanwhile, reminds us of how prevalent Anglo-Saxonist interpretations of American history once were. One recalls that the Turnerites and the New Historians in their different ways both started from the assumption that Anglo-Saxonism was a myth and a menace that needed discrediting. Yankee New England seemed on the wane by the late nineteenth century, Adams explains, but old-line New Englanders could use Anglo-Saxonism to participate vicariously in the apparent triumphs of their group in the American West and elsewhere. 